\title{
Mikorizoremediasi: Asosiasi Fungi Mikoriza Arbuskula dalam Meningkatkan Kemampuan Penyerapan Logam pada Tanaman Hiperakumulator di Lahan Pertambangan
}

\author{
Mycorizoremediation: Association of Arbuscular Mycorrhizal Fungi to \\ Increase Metal Absorption Ability in Hyperaccumulator Plants at Mining \\ Land
}

\section{FERNANDO CHRISTOFER, SIORATNA PUSPITA SARI, KATRINA SAPULETTE, MELISA ANGGAYNI, ELISABETH HUTAGALUNG, WAHYU IRAWATI*}

Biology Education Department, Universitas Pelita Harapan.

M.H. Thamrin Boulevard 1100, Lippo Karawaci,

Tangerang 15811, Banten, Indonesia.

*w.irawati3@gmail.com

\begin{tabular}{|c|c|}
\hline ARTICLE INFO & ABSTRACT \\
\hline $\begin{array}{l}\text { Article history: } \\
\text { Received } 2 \text { December } 2020 \\
\text { Accepted } 8 \text { December } 2021 \\
\text { Published } 31 \text { January } 2022\end{array}$ & $\begin{array}{l}\text { Post-mining land has the characteristics of hard soil and toxic because it has been contaminated by heavy metal } \\
\text { wastes, such as } \mathrm{As}, \mathrm{B}, \mathrm{Cd}, \mathrm{Cu}, \mathrm{Hg}, \mathrm{Mo}, \mathrm{Ni}, \mathrm{Pb}, \mathrm{Se} \text {, and } \mathrm{Zn} \text {. This condition makes it unplantable and dangerous } \\
\text { for the survival of living things, so it requires reclamation to restore its condition. One practical solution that } \\
\text { applies as the reclamation is using mycorrhizoremediation technology. This technology utilizes the association of } \\
\text { hyperaccumulator plants with arbuscular mycorrhizal fungi to absorb metals in post-mining land. This paper }\end{array}$ \\
\hline $\begin{array}{l}\text { Keywords: } \\
\text { Arbuscular mycorrhizal fungi } \\
\text { Hyperaccumulator plants } \\
\text { Metal absorption } \\
\text { Mycorizoremediation } \\
\text { Post-mining land }\end{array}$ & $\begin{array}{l}\text { aims to examine the mechanism and increase metal absorption ability in hyperaccumulator plants associated with } \\
\text { the fungi in post-mining land. The method used in this research was the literature review method. The results of } \\
\text { this study are the secondary data that successfully proves the use of mycorrhizoremediation as one of the solutions } \\
\text { from the post-mining land reclamation effort. Arbuscular mycorrhizal fungi had the potential to increase the } \\
\text { ability and effectiveness of metal absorption in hyperaccumulator plants. It helps plants expand the root } \\
\text { absorption area by absorbing heavy metals, water, and other nutrients by colonizing plant roots. Further research } \\
\text { is suggested to assess the effectiveness of hyperaccumulator plant vegetation density associated with the fungi in } \\
\text { a post-mining area. }\end{array}$ \\
\hline
\end{tabular}

\section{INFORMASI ARTIKEL}

Histori artikel:

Diterima 2 Desember 2020

Disetujui 8 Desember 2021

Diterbitkan 31 Januari 2022

\section{Kata kunci:}

Fungi mikoriza arbuskula

Lahan pascatambang

Mikorizoremediasi

Penyerapan logam

Tanaman hiperakumulator

\section{ABSTRAK}

Lahan pascatambang memiliki karakteristik tanah yang keras dan bersifat toksik, karena telah tercemar limbah logam berat seperti $\mathrm{As}, \mathrm{B}, \mathrm{Cd}, \mathrm{Cu}, \mathrm{Hg}$, $\mathrm{Mo}, \mathrm{Ni}, \mathrm{Pb}, \mathrm{Se}$, dan $\mathrm{Zn}$. Kondisi tersebut membuat lahan pascatambang menjadi lahan yang tidak dapat ditanami tanaman dan berbahaya bagi keberlangsungan makhluk hidup, sehingga memerlukan upaya reklamasi untuk memulihkan kondisi tanah. Salah satu solusi efektif yang dapat digunakan sebagai upaya reklamasi lahan pascatambang adalah dengan menerapkan teknologi mikorizoremediasi. Teknologi tersebut memanfaatkan asosiasi tanaman hiperakumulator dengan fungi mikoriza arbukular untuk menyerap logam yang berada di lahan pascatambang. Makalah ini bertujuan untuk mengkaji mekanisme dan peningkatan kemampuan penyerapan logam pada tanaman hiperakumulator yang berasosiasi dengan fungi mikoriza arbuskula di lahan pascatambang. Metode penulisan makalah ini adalah kajian literatur. Hasil temuan dari makalah ini adalah kumpulan data sekunder yang membuktikan keberhasilan pemanfaatan mikorizoremediasi sebagai salah satu solusi dari upaya reklamasi lahan pascatambang. Fungi mikoriza arbuskula memiliki potensi untuk meningkatkan kemampuan dan efektivitas penyerapan logam pada tanaman hiperakumulator. Fungi mikoriza arbuskula membantu tanaman untuk memperluas wilayah penyerapan akar dalam menyerap logam berat, air, dan unsur hara lainnya dengan mengolonisasi akar tanaman. Kajian berikutnya disarankan dapat mengkaji efektivitas kerapatan vegetasi tanaman hiperakumulator yang berasosiasi dengan fungi mikoriza arbuskula pada suatu lahan pascatambang. 


\section{Pendahuluan}

Pertambangan merupakan salah satu kegiatan industri yang bertujuan untuk mengekstraksi dan mengelola kekayaan mineral atau bahan tambang lainnya dari dalam bumi. Aktivitas pertambangan yang dikelola dengan optimal akan memberikan banyak dampak positif bagi kemajuan teknologi dan industri, memenuhi kebutuhan energi, serta dapat meningkatkan pertumbuhan ekonomi dan pembangunan (Munir \& Setyowati, 2017; Thamrin \& Raden, 2018). Adapun setiap aktivitas pertambangan perlu memerhatikan aspek manajemen pengelolaan lahan pascatambang sebagai upaya pemulihan dan perbaikan lahan tambang melalui reklamasi dan revegetasi (Adman, Hendrarto \& Sasongko, 2012). Hal ini dikarenakan aktivitas pertambangan banyak menghasilkan limbah logam berat seperti $\mathrm{As}, \mathrm{B}, \mathrm{Cd}, \mathrm{Cu}, \mathrm{Hg}$, Mo, Ni, Pb, Se, dan $\mathrm{Zn}$ yang dapat mencemari lingkungan dan berbahaya bagi keberlangsungan makhluk hidup (Ahmad, 2018; Nuriadi et al., 2013).

Lahan pascatambang merupakan salah satu konsekuensi dari aktivitas pertambangan. Lahan pascatambang memiliki karakter fisik yang keras dan mengalami kerusakan pada permukaan atau tutupan tanah, kedalaman efektif tanah menjadi dangkal, terdapat lapisan tanah yang menghambat pertumbuhan tanaman (Munir \& Setyowati, 2017; Hirfan, 2016), dan memiliki tingkat kepadatan tanah yang tinggi karena sering dilalui oleh kendaraan atau alat-alat berat selama proses pertambangan (Mashud \& Manaroinsong, 2014). Karakteristik kimia lahan pascatambang memiliki sifat toksik yang diakibatkan dari pencemaran limbah logam berat (Ahmad, 2018; Hidayanti, 2013) dan tidak lagi mampu memberikan unsur-unsur hara bagi tumbuhan (Hirfan, 2016). Tidak adanya suatu kegiatan reklamasi yang sesuai untuk pengembalian kondisi tanah, akan menyebabkan kualitas tanah menurun. Penurunan tersebut dapat dilihat dari berkurangnya kesuburan tanah dan menurunnya kadar air pada tanah (Ulfa et al., 2011). Lahan pascatambang pada umumnya banyak dialihfungsikan menjadi kawasan kehutanan, pertanian, lokasi wisata, dan perkebunan melalui kegiatan reklamasi dan revegetasi lahan tambang (Adman et al., 2012). Berdasarkan fakta tersebut diperlukan upaya untuk mengembalikan unsur hara dan meningkatkan kualitas lahan pascatambang yang salah satunya dengan cara mikorizoremediasi.

Mikorizoremediasi merupakan teknologi rehabilitasi lingkungan dengan memanfaatkan sistem perakaran tanaman hiperakumulator yang berasosiasi dengan fungi mikoriza arbuskula (Prasetyo et al., 2017). Tanaman hiperakumulator dikenal sebagai tanaman yang memiliki struktur morfologi dan fisiologi akar yang terspesialiasi untuk dapat menyerap dan mengakumulasi logam (Hidayanti, 2013). Tanaman ini diketahui dapat berasosiasi dengan fungi mikoriza arbuskula untuk meningkatkan kemampuan penyerapan logam seperti $\mathrm{P}, \mathrm{K}, \mathrm{Ca}, \mathrm{Mg}, \mathrm{Fe}$, dan $\mathrm{Cu}$ (Dwityaningsing et al., 2019). Jaringan hifa yang panjang pada fungi mikoriza arbuskula akan melekat dengan jaringan akar dan memperluas daerah penyerapan air dan unsur hara pada akar tanaman hiperakumulator. Hal ini dikarenakan kemampuannya yang dapat menembus pori-pori tanah hingga pada bagian mikronya (Suryati, 2017). Penerapan teknologi mikorizoremediasi diharapkan dapat menjadi salah satu metode yang menjanjikan untuk merehabilitasi lahan pascatambang.

\section{Kondisi Lahan Pascatambang}

Permasalahan dari aktivitas pertambangan yang telah selesai dipakai adalah upaya mereklamasi lahan pascatambang. Perubahan lingkungan pascatambang menyebabkan perubahan pada kondisi tanah. Kegiatan pertambangan menyebabkan struktur tanah penutup menjadi rusak. Hal ini dapat terjadi karena struktur tanah atas bercampur dengan berbagai material kasar dan menyebabkan posisinya tergantikan oleh lapisan bawahnya yang tidak terlalu subur, sehingga lapisan tanah atas tertimbun di lapisan bawah (Subowo, 2011). Pernyataan tersebut didukung oleh Allo (2016) yang menyatakan bahwa kondisi tanah pascatambang akan menunjukkan perubahan fisik, kimia, dan biologi seperti solum tanah yang dangkal dan tidak adanya lapisan atas pada tanah. Hal ini tentu menyebabkan kondisi tanah yang menjadi tidak stabil dan buruknya komposisi material tanah akibat kinerja alat berat selama proses pertambangan. Tingkat keasaman tanah juga menjadi sangat rendah dan memungkinkan adanya gejala toksisitas apabila terus menerus dibiarkan. Sejalan dengan Hidayat, Rustiadi, dan Kartodihardjo (2015) yang menyatakan bahwa penggunaan suatu lahan untuk aktivitas pertambangan menyebabkan degradasi pada kondisi tanah. Degradasi tanah yang terjadi merupakan dampak dari kerusakan fisik yang dialami oleh tanah. Hal ini mengakibatkan hilangnya unsur hara dan mineral dari dalam tanah yang bermanfaat bagi pertumbuhan tanaman (Hirfan, 2016). Menurut Huzeini et al. (2019) kerusakan lahan akan bersifat irreversible atau sulit untuk dikembalikan seperti kondisi semula. Sejalan dengan itu Sofyan et al. (2017) mengatakan bahwa selain pertambangan dapat memberikan keuntungan ekonomi tetapi juga dapat merugikan dengan adanya kerusakan lahan. Kerusakan yang timbul seperti $\mathrm{pH}$ tanah yang asam dan kerusakan struktur tanah yang diakibatkan kinerja alat berat membuat kandungan organik dalam tanah menjadi rendah ataupun tercemar.

Pencemaran logam berat di lahan pascatambang menjadi salah satu faktor utama yang menyebabkan toksisitas dan penurunan kualitas kandungan zat hara di dalam tanah. Jenis logam berat yang menjadi bahan pencemar bergantung pada mineral tambang dan proses pertambangan. Logam berat memiliki sifat yang tidak dapat terurai, mudah terakumulasi dalam rantai makanan, dan tersedimentasi (Khan et al., 2018; Rosahada et al., 2018; Setiawan, 2015; Irhamni et al., 2017). Logam berat dibedakan menjadi dua jenis berdasarkan sifatnya yaitu logam berat esensial dan non esensial. Logam berat esensial adalah jenis logam yang dalam jumlah tertentu yang dibutuhkan oleh organisme untuk proses fisiologis dan metabolisme, seperti $\mathrm{Zn}, \mathrm{Cu}, \mathrm{Fe}, \mathrm{Co}$, dan Mn (Irhamni et al., 2017). Kandungan logam berat esensial yang berlebihan di dalam tubuh makhluk hidup dapat menimbulkan berbagai jenis penyakit, kerusakan organ, keracunan, dan kematian dengan proses jangka waktu yang panjang (Bijang et al., 2018). Logam berat non esensial adalah logam yang keberadaannya dalam tubuh masih belum diketahui manfaatnya dan bersifat toksik, seperti $\mathrm{Hg}, \mathrm{Cd}, \mathrm{Pb}$, dan Cr (Khan et al., 2018). Beberapa hasil penelitian telah 
mengungkapkan sejumlah kandungan logam berat di lahan pasacatambang, seperti $\mathrm{Pb}, \mathrm{Hg}$, dan $\mathrm{Cd}$ di lahan pascatambang batubara (Sarie, 2019) ataupun cemaran $\mathrm{Cu}$ yang banyak ditemukan di pertambangan emas (Nuriadi et al., 2013). Perencanaan reklamasi lahan pascatambang yang tidak terintegrasi sejak awal mengakibatkan permasalahan yang memberikan dampak negatif bagi hayati tanah (Dariah et al., 2010). Menurut Munir dan Setyowati (2017) reklamasi sangat penting untuk dilakukan pada lahan pascatambang dengan bertujuan untuk mencegah erosi dan membuat lahan tetap produktif. Lahan pascatambang selayaknya dapat dimanfaatkan kembali untuk berbagai tujuan.

\section{Potensi Fungi Mikoriza Arbuskula}

Fungi mikoriza arbuskula merupakan kelompok jamur yang mampu melakukan simbiosis mutualisme dengan sistem perakaran tumbuhan (Sukmawaty \& Asrian, 2015). Mikoriza berasal dari bahasa Yunani "miko" atau "mykus" yang berarti cendawan dan "rhiza" yang berarti akar tanaman, sehingga dapat diartikan sebagai bentuk hubungan mutualistik antara jamur (mykus) tanah dengan perakaran (rhiza) tumbuhan tingkat tinggi (Idhan \& Nursjamsi, 2016). Pernyataan tersebut didukung oleh Pulungan yang menyatakan bahwa mikoriza merupakan interaksi fungi dengan akar tanaman yang sifatnya menguntungkan bagi masing-masing organisme (Pulungan, 2018). Mikoriza akan mengolonisasi apoplast dan sel korteks untuk mendapatkan karbon dari tumbuhan, sementara tumbuhan akan mendapat mineral-mineral tanah dari fungi melalui hifa dalam tanah yang dapat menyediakan kebutuhan untuk metabolisme tumbuhan. Menurut Muryati et al. (2016) fungi mikoriza arbuskula bersimbiosis dengan akar dan berperan penting dalam pertumbuhan tanaman, baik secara ekologis maupun agronomis dengan cara meningkatkan serapan fospor dan unsur hara lain seperti N, K, Zn, Co, S, dan Mo dari dalam tanah, meningkatkan ketahanan terhadap kekeringan, memperbaiki agregasi tanah, meningkatkan pertumbuhan mikroba tanah yang bermanfaat bagi pertumbuhan tumbuhan inang, serta sebagai pelindung tanaman dari infeksi patogen akar. Mikoriza memiliki prinsip untuk menginfeksi sistem perakaran tanaman dan memproduksi jalinan hifa secara intensif sehingga tanaman yang bersimbiosis dengan mikoriza tersebut mampu meningkatkan kapasitas dalam penyerapan unsur hara (Arisutanti \& Purawanti, 2013). Terjadinya perluasan bidang serapan akar pada mikoriza, disebabkan oleh hifa eksternal yang tumbuh dan berkembang melalui bulu akar dan kemudian miselia fungi mikoriza arbuskula dapat tumbuh dan menyebar keluar akar sekitar lebih dari $9 \mathrm{~cm}$ (Talanca, 2010).

Fungi mikoriza arbuskula memiliki dua fase miselium pada masa perkembangannya yaitu miselium eksternal yang berada di dalam tanah dengan spora yang dibentuk dan tersebar di sekitar akar, serta miselium internal yang berada di dalam akar tanaman bermikoriza, terdiri atas hifa tidak bercabang yang intraseluler, hifa interseluler, arbuskula, dan vesikula, serta hifa yang melingkar-lingkar atau hifa gelung (Sukmawaty \& Asrian, 2015). Hifa pada fungi mikoriza arbuskula terbentuk dari perkecambahan spora, yang berperan dalam menyerap unsur hara dan air. Struktur arbuskula berbentuk seperti pohon terbentuk dari cabangcabang hifa intraradikal yang berada antara dinding sel dan membran sel dan berperan penting sebagai tempat pertukaran unsur hara dan karbon antara fungi mikoriza arbuskula dan tanaman inang, serta tempat penyimpanan sementara mineral, nutrisi, dan gula (Muryati et al., 2016). Fungi mikoriza arbuskula juga memegang peranan penting dalam melindungi akar tanaman dari unsur toksik seperti logam berat. Mekanisme perlindungan terhadap logam berat dan unsur toksik oleh fungi mikoriza arbuskula dapat melalui efek filtrasi, menonaktifkan secara kimiawi, atau akumulasi logam dalam hifa jamur, sehingga dapat dikatakan bahwa simbiosis yang terjadi menyebabkan peningkatan toleransi tanaman terhadap logam beracun, baik melalui akumulasi logam-logam dalam hifa eksternal sehingga mengurangi serapannya ke dalam tanaman inang maupun mekanisme sekresi logam oleh hifa ekternal (Arisusanti \& Purwani, 2013). Gambar 1 Berikut ini merupakan struktur fungi mikoriza arbuskula secara umum:

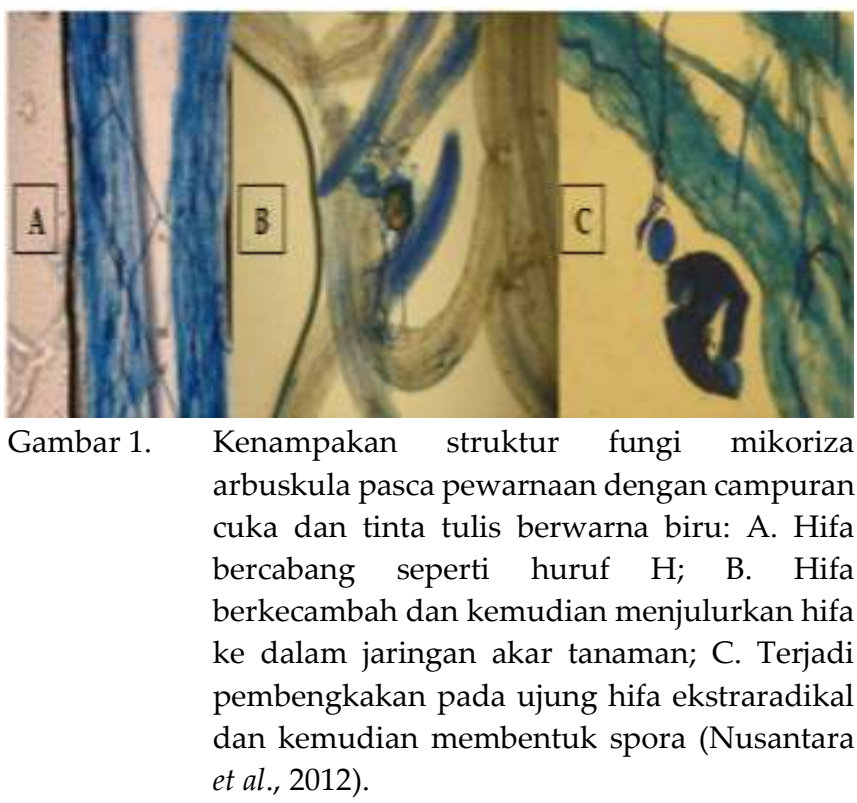

\section{Potensi Tanaman Hiperakumulator}

Remediasi pada lingkungan tercemar memiliki beberapa bentuk pendekatan atau solusi penyelesaian, salah satunya dengan menggunakan tanaman yang disebut dengan teknologi fitoremediasi. Fitoremediasi merupakan proses pengubahan zat atau polutan pencemar yang memiliki rantai molekul kompleks menjadi sederhana dan tidak berbahaya, sehingga dapat berguna bagi pertumbuhan tanaman itu sendiri maupun bahan yang berguna secara ekonomi (Irhamni et al., 2018). Fitoremediasi berasal dari kata "phyto" yang berarti tumbuhan dan "remediation" yang berarti memulihkan atau membersihkan, sehingga dapat dikatakan bahwa fitoremidiasi berarti sistem pada tanaman yang dapat mengubah polutan menjadi substansi yang tidak berbahaya, bahkan menjadi bahan yang dapat digunakan kembali (Dwityangsing et al., 2019).

Tanaman yang digunakan dalam proses fitoremediasi merupakan jenis tanaman dengan kemampuan akumulasi logam berkonsentrasi tinggi sehingga bersifat hiperakumulator. Tanaman pada umumnya hanya mampu mengakumulasi logam setara dengan 0,001\%, akan tetapi 
pada tumbuhan hiperakumulator logam mampu diakumulasi hingga 11\% berat kering tanaman (Irhamni et all., 2018). Tanaman hiperakumulator dapat mengakumulasi logam di lingkungan dengan batas kadar tertentu yang dipengaruhi oleh jenis logam dan jenis tanaman hiperakumulator (Hidayanti, 2013). Hal ini seperti Viola calaminaria dan Alyssum bertolinii yang masing-masing dapat menyerap $\mathrm{Zn}$ dan $\mathrm{Ni}$ sebanyak $1 \%$ dari berat tanaman. Contoh lainnya adalah Thlaspi caerulencens yang mampu mengakumulasi $\mathrm{Zn}$ dan $\mathrm{Cd}$ dengan masing-masing akumulasi logam minimal sebesar 10.000 dan $100 \mu \mathrm{g} / \mathrm{g}$ (Suharno \& Sancayaningsih, 2013). Menurut penelitian Ingwersen, Bücherl, Neumann, dan Streck (2006) akumulasi logam Cd oleh Thlaspi caerulencens sangat dipengaruhi oleh mekanisme kinetika desorpsi yang terjadi di dalam jaringan akar. Menurut Komarawidjaja dan Garno (2016) tanaman Chrysopogon zizanoides juga dapat memulihkan kondisi sungai yang tercemar logam fosfat $(\mathrm{P})$ dan nitrogen $(\mathrm{N})$, dengan cara mengurangi konsentrasi $\mathrm{P}$ sebesar $98 \%$ setelah 3-4 minggu dan konsentrasi N sebesar 7174\% dalam 4-5 minggu waktu penelitian.

Tanaman hiperakumulator memiliki beberapa karakteristik yang membuatnya tidak mengalami keracunan logam walaupun berada di lingkungan yang memiliki konsentrasi logam tinggi di antaranya, tahan terhadap logam konsentrasi tinggi, tingkat laju penyerapan logam yang tinggi dibanding tanaman pada umumnya, memiliki kemampuan akumulasi, translokasi dan serapan logam yang memadai, toleransi terhadap genangan air dan kondisi kekeringan ekstrim, toleransi terhadap $\mathrm{pH}$ dan salinitas tinggi, serta memiliki karakteristik akar dan kedalaman zona akar yang sesuai dengan kondisi lingkungan (Sarma, 2011). Hal sebaliknya yang terjadi pada tanaman non-hiperakumulator yang akan mengalami gejala keracunan berupa pertumbuhan yang terhambat pada bagian akar, penurunan laju fotosintesis karena adanya penurunan konsentrasi klorofil $b$, dan penurunan area daun. Hiperakumulator memiliki kemampuan mempercepat terlarutnya logam pada risosfer. Akar tanaman hiperakumulator merupakan jaringan pertama yang terpapar langsung dengan logam di dalam tanah (Hidayanti, 2013). Menurut Komarawidjaja \& Garno (2016) kemampuan tanaman hiperakumulator dalam menyerap polutan logam didukung oleh karakteristik morfologi dan fisiologi sistem penetrasi akar yang dalam dan ekstensif sehingga dapat menahan buangan air, serta toleransi yang tinggi terhadap kondisi lingkungan yang kurang baik, seperti kadar keasaman tanah yang tinggi dan toksisitas logam. Logam yang berada di dalam tanah masuk ke dalam tanaman melalui akar dengan cara difusi aktif atau melalui transporter non-spesifik pada konsentrasi logam yang tinggi (Suharno \& Sancayaningsih, 2013).

\section{Mikorizoremediasi sebagai Asosiasi Fungi Mikoriza Arbuskula dengan Tanaman Hiperakumulator Kondisi Lahan Pascatambang}

Fungi mikoriza arbuskula sebagai mikroorganisme tanah memiliki potensi untuk meningkatkan pertumbuhan tanaman pada lahan pascatambang ataupun lahan marginal yang kekurangan air melalui simbiosis jamur dengan akar tumbuhan sehingga meningkatkan daerah serapan akar dalam mengakses unsur hara di dalam tanah (Ulfa et al., 2011). Penelitian terbaru diketahui bahwa fungi mikoriza arbuskula dapat dimanfaatkan dalam remediasi logam berat pada lahan bekas tambang dengan berasosiasi pada tanaman hiperakumulator logam berat untuk meningkatkan daya penyerapan logam berat pada lahan tercemar (Suharno \& Sancayaningsih, 2013). Kemampuan fungi mikoriza arbuskula kini telah dikembangkan dalam teknologi yang dikenal sebagai mikorizoremediasi yaitu asosiasi jamur dengan akar tanaman terkhusus tanaman hiperakumulator sebagai salah satu alternatif untuk meningkatkan dan mengembangkan kemampuan tanaman dalam usaha remediasi lahan tambang tercemar logam berat (Kartika, Lizawati \& Hamzah, 2018). Hasil penelitian Arisusanti dan Purwani menunjukkan hubungan yang sangat erat antara fungi mikoriza arbuskula dengan tanaman hiperakumulator dalam proses remediasi lahan bekas tambang yang tercemar logam berat (Arisusanti \& Purwani, 2013).

Tabel 1. Asosiasi fungi mikoriza arbuskula dengan tanaman hiperakumulator dan jenis logam yang diserap (Suharno \& Sanacayaningsih, 2013).

\begin{tabular}{ccc}
\hline $\begin{array}{c}\text { Fungi mikoriza } \\
\text { arbuskula }\end{array}$ & Tanaman hiperakumulator & Logam \\
\hline Glomus intraradices & Eucalyptus camaldulensis & $\mathrm{Cd}$ \\
Acaulospora delicata & Plantago lanceolate & $\mathrm{Cr}$ \\
Glomus caledonium & Elsholtzia splendens & $\mathrm{Cu}$ \\
Glomus caledonium & Elsholtzia splendens & $\mathrm{P}$ \\
Glomus fasciculatum & Dahlia pinnata & $\mathrm{Pb}$ \\
Glomus caledonium & Zea mays & $\mathrm{Zn}$ \\
\hline
\end{tabular}

Tanaman hiperakumulator memiliki tingkat toleransi dan kemampuan untuk mengakumulasi logam berat melalui mekanisme utama yaitu penyerapan unsur logam oleh akar tanaman, akumulasi logam berat pada tunas, dan pengangkutan oleh xilem ke organ tumbuhan (Suharno \& Sancayaningsih, 2013; DalCorso et al., 2019). Kemampuan ini dapat dilakukan oleh tanaman hiperakumulator namun dalam batas tertentu sehingga asosiasi dengan fungi mikoriza arbuskula pada tanaman hiperakumulator dapat memberi perlindungan dan mendukung aktivitas tanaman tersebut dalam menyerap racun melalui efek filtrasi, kompleksasi, dan akumulasi (Arisusanti \& Purwani, 2013). Perlindungan yang diberikan oleh mikoriza dapat meningkatkan toleransi tanaman pada logam berat sehingga meningkatkan potensi tumbuhnya tanaman pada lahan tercemar serta meningkatkan potensi akumulasi dari tanaman hiperakumulator dalam remediasi lingkungan (Nadeak et al., 2015). Peningkatan toleransi dan akumulasi tanaman oleh fungi mikoriza arbuskula menjadikannya sebagai salah satu agen penting dalam proses fitoremediasi (Takacs, 2012). Tabel 1 menyajikan data asosiasi fungi mikoriza arbuskula dengan tanaman hiperakumulator beserta jenis logam yang diserap:

\section{Mekanisme Mikorizoremediasi}

Tanaman hiperakumulator memiliki kemampuan fitoremediasi yang dapat diasosiasikan dengan fungi mikoriza arbuskula sebagai agen yang membantu meningkatkan fitoremediasi untuk mengatasi polutan logam berat. Berdasarkan hasil penelitian, diketahui bahwa fungi 
mikoriza arbuskula memiliki potensi dalam meningkatkan fitostabilisasi dengan menyerap dan mengikat unsur-unsur logam berat pada tanah (Arisusanti \& Purwani, 2013). Sejauh ini terdapat enam jenis fungi mikoriza arbuskula yang telah diuji coba dapat mengikat unsur-unsur logam berat, di antaranya adalah Glomus claroideum, Glomus microcarpum, dan Glomus sinuosa (Zaidi et al., 2012).

Fungi mikoriza arbuskula dapat meningkatkan pertumbuhan tanaman pada kondisi lahan tercemar logam berat karena ditunjang oleh kemampuan fungi mikoriza arbuskula dalam meningkatkan penyerapan logam berat dan mengimobilisasikan dan menimbunnya di dalam hifa sehingga mengurangi resapan logam berat yang berlebih langsung ke dalam sel tumbuhan (Nadeak et al., 2015). Fungi mikoriza arbuskula dapat berperan sebagai fitoekstraksi yaitu penyerapan logam dan mentransfernya dari akar ke pucuk dan immobilisasi logam atau disebut sebagai fitostabilisasi (Tuheteru et al., 2017). Fungi mikoriza arbuskula melakukan mekanisme fitoekstraksi dengan membantu tanaman mengakumulasi kandungan logam, memfasilitasi pertumbuhan, dan produksi biomassa, serta meningkatkan toleransi tanaman terhadap logam berat, sedangkan mekanisme fitostabilisasi logam oleh fungi mikoriza arbuskula dilakukan dengan cara logam disimpan di dalam struktur jaringan fungi yang terdapat di dalam akar tanaman, tepatnya pada vakuola, dinding sel, dan arbuskular (Javaid, 2011). Menurut penelitian Suharno \& Sancayaningsih (2013) mikoriza memberikan kontribusi terhadap imobilisasi logam berat pada tanaman hiperakumulator dengan meningkatkan fitostabilisasi yang bekerja secara sinergis dengan tanaman. Menurut Nadeak et al., (2015) serapan unsur logam pada fungi mikoriza arbuskula akan disimpan di dalam hifa dan vesikula-vesikula arbuskular sehingga kadar logam berat di dalam akar tanaman akan jauh lebih besar bila dibandingkan di dalam tajuk. Hal ini disebabkan karena hifa dari fungi mikoriza arbuskula mengakumulasi unsur logam dan menghambat penyerapan unsur logam hingga masuk ke dalam tajuk tanaman.

Fungi mikoriza arbuskula pada lahan tambang dapat menjaga stabilisasi tanah dengan membuat jaring-jaring eksternal hifa yang membentuk struktur makro dan mikroagregat tanah (Orlowska et al., 2011). Peran fungi mikoriza arbuskula dalam stabilisasi tanah didukung oleh beberapa senyawa penting yang di antaranya adalah glomalin. Glomalin merupakan senyawa yang diproduksi oleh fungi untuk membantu proses pembentukan mikroagregat tanah sehingga perkembangan hifa semakin meningkat dan memungkinkan untuk menghasilkan bahan organik bagi tanah dengan menyediakan habitat bagi mikroba tanah (Suharno \& Sancayaningsih, 2013). Mekanisme lain yang dapat dilakukan oleh fungi mikoriza arbuskula dalam menurunkan konsentrasi logam pada tanah adalah dengan mengikat ion-ion logam pada kitin di dinding sel fungi dan melalui vesikel-vesikel fungi yang menyimpan ataupun mengisolasi senyawa-senyawa toksik tersebut, sehingga penggunaan fungi mikoriza arbuskula dinilai tepat untuk memperbaiki kondisi tanah dari limbah logam berat (Arisusanti \& Purwani, 2013).

\section{Hasil Mikorizoremediasi}

Kemampuan yang dimiliki oleh tanaman hiperakumulator dalam mengakumulasi logam menjadikan tanaman tersebut digunakan secara luas dan komersial dalam teknik fitoremediasi. Beberapa contoh jenis tanaman hiperakumulator yang memiliki kemampuan dalam mengakumulasi logam berat di antaranya adalah 1) Alyssum corsicum mampu mengakumulasikan nikel (Ni) hingga 400 $\mathrm{kg} / \mathrm{h}$ dalam waktu 1 tahun, 2) Thlaspi caerulescence mampu mengakumulasi kadmium (Cd) hingga $10 \mathrm{~kg} / \mathrm{H}$ dalam waktu 1 tahun, dan seng (Zn) lebih dari $30.000 \mathrm{mg} / \mathrm{kg}$ berat kering tajuknya, 3) Salix viminalis mampu mengakumulasi $\mathrm{Cd}$

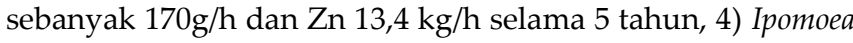
spp mampu mengakumulasi 35,70 ppm sianida (CN), 5) Mikania cordata mampu mengakumulasi 11,65 ppm timbal $(\mathrm{Pb})$ dan lain sebagainya (Hidayanti, 2013). Adapun penelitian mengenai pemanfaatan fungi sebagai agen bioremediasi atau mikoremediator juga telah banyak dilakukan. Beberapa jenis fungi sudah dimanfaatkan untuk menyerap logam berat, seperti fungi pelarut kalium dari golongan Gliocladium yang mampu menyerap $\mathrm{Pb}$ hingga 100 ppm (Azizah et al., 2020), Saccharomyces cerevisiae yang mampu menyerap Cd dan Pb (Damodaran, Suresh, \& Mohan, 2011), sekelompok jamur Fusarium solani, Aspergillus niger, A. flavus, dan Penicillium chrysogenum yang memiliki daya ketahanan terhadap $\mathrm{Cr}$ dan $\mathrm{Pb}$ (Iram et al., 2012), ataupun jamur $A$. awamori, Trichoderma viride, dan Phanerochaete chrysosporium yang toleran terhadap $\mathrm{Ni}, \mathrm{Cd}, \mathrm{Cr}$, dan $\mathrm{Pb}$ (Joshi et al., 2011).

Tanaman hiperakumulator memiliki batas kemampuan dalam mengakumulasi logam berat. Hidayanti menjelaskan bahwa secara umum batas kemampuan tanaman hiperakumulator yaitu apabila mengakumulasi logam lebih dari $1 \%$ dari berat total kering tajuknya, oleh karena itu berbagai uji coba telah dilakukan untuk meningkatkan kemampuan tanaman hiperakumulator (Hidayanti, 2013). Pemanfaatan fitoremediasi yang melibatkan simbiosis fungi mikoriza arbuskula terbukti lebih efektif dibandingkan dengan perlakuan tanpa asosiasi fungi mikoriza arbuskula (Suharno \& Sancayaningsih, 2013). Beberapa penelitian telah menguji asosiasi fungi mikoriza arbuskula pada tanaman hiperkumulator, salah satu contohnya yaitu asosiasi mikoriza Glomus fasciculatum pada tanaman Dahlia pinnata. Hasil uji Arisusanti \& Purwani (2013) menunjukkan perbedaan efisiensi serapan logam $\mathrm{Pb}$ pada Dahlia pinnata sebelum dan sesudah diasosiasi dengan fungi mikoriza arbuskula. Berikut data pengaruh fungi mikoriza arbuskula terhadap akumulasi logam Pb pada Dahlia pinnata dapat dilihat pada Tabel 2.

Tabel 2 menjelaskan bahwa efisiensi serapan logam $\mathrm{Pb}$ meningkat seiring dengan penambahan fungi mikoriza arbuskula pada tanaman Dahlia pinnata. Fungi mikoriza arbuskula juga dapat meningkatkan akumulasi logam $\mathrm{Pb}$ pada akar tanaman Dahlia pinnata dan menghambat akumulasi $\mathrm{Pb}$ pada bagian batang dan daun. Hal tersebut terjadi karena fungi mikoriza memiliki kemampuan yaitu toleran terhadap logam berat. Suharno dan Sancayaningsih (2013) menjelaskan bahwa fungi mikoriza arbuskula mampu menyerap dan mengakumulasi logam dalam biomassa dan akar tanaman inang. Sejalan dengan pendapat tersebut Ashofie dan Prasetya menjelaskan bahwa fungi mikoriza arbuskula menyerap dan mengikat logam berat oleh gugus 
karboksil dari senyawa hemiselulose yang dihasilkan diantara matriks mikoriza dan tanaman inang (Ashofie \& Prasetya, 2019).

Tabel 2. Pengaruh fungi mikoriza arbuskula terhadap efisiensi serapan logam $\mathrm{Pb}$ pada Dahlia pinnata (Arisusanti \& Purwani, 2013).

\begin{tabular}{cc}
\hline Perlakuan & Efisiensi serapan $\mathrm{Pb}$ \\
\hline 0 gram mikoriza dan 200 ppm $\mathrm{Pb}\left(\mathrm{NO}_{3}\right)_{2}$ & $8,07 \%$ \\
5 gram mikoriza dan 200 ppm $\mathrm{Pb}\left(\mathrm{NO}_{3}\right)_{2}$ & $9,06 \%$ \\
10 gram mikoriza dan 200 ppm $\mathrm{Pb}\left(\mathrm{NO}_{3}\right)_{2}$ & $11,78 \%$ \\
15 gram mikoriza dan 200 ppm $\mathrm{Pb}\left(\mathrm{NO}_{3}\right)_{2}$ & $12,18 \%$ \\
20 gram mikoriza dan 200 ppm $\mathrm{Pb}\left(\mathrm{NO}_{3}\right)_{2}$ & $13,98 \%$ \\
25 gram mikoriza dan 200 ppm $\mathrm{Pb}\left(\mathrm{NO}_{3}\right)_{2}$ & $18,34 \%$ \\
\hline
\end{tabular}

Hasil uji coba Ekawati et al. (2016) juga menunjukkan bahwa mikorizoremediasi dapat meningkatkan pertumbuhan tanaman dan menurunkan kadar logam berat dalam tanah (Ekawati et al., 2016). Data yang didapatkan dalam penelitiannya menunjukkan perbedaan kemampuan tanaman hiperakumulator sebelum dan sesudah diasosiasikan dengan fungi mikoriza arbuskula. Perbedaan tersebut dilihat dari hasil penurunan kadar logam berat dalam tanah yaitu kadar Cr sebesar 200,36 ppm menjadi 8,38 ppm, kadar Ni 1437,48 ppm menjadi 207,85 ppm, kadar Fe 10.1293,32 ppm menjadi 763,69 ppm, kadar Mn 2791,71 ppm menjadi 195,85 ppm dan kadar Zn 138,42 ppm menjadi 8,18 ppm.

\section{KESIMPULAN}

Dapat disimpulkan bahwa lahan pascatambang memiliki karakteristik yang keras dan mengandung banyak mengandung logam berat, sehingga memerlukan upaya reklamasi untuk dapat dipergunakan kembali. Pemanfaatan mikorizoremediasi sebagai asosiasi tanaman hiperakumulator dengan fungi mikoriza arbukula diketahui dapat menjadi solusi dari upaya reklamasi lahan pascatambang. Fungi mikoriza arbuskula memiliki potensi untuk meningkatkan kemampuan dan efektivitas penyerapan logam pada tanaman hiperakumulator. Fungi mikoriza arbuskula membantu tanaman untuk memperluas wilayah penyerapan akar dalam menyerap logam berat, air, dan unsur hara lainnya dengan mengolonisasi akar tanaman. Kajian selanjutnya disarankan dapat mengkaji efektivitas kerapatan vegetasi tanaman hiperakumulator yang berasosiasi dengan fungi mikoriza arbuskula pada suatu lahan pascatambang.

\section{PERSANTUNAN}

Ucapan terima kasih diberikan kepada semua penulis artikel yang tulisan dan/atau gambarnya disitasi sebagai sumber referensi dalam menyusun kajian literatur ini.

\section{DAFTAR PUSTAKA}

Adman, B., Hendrarto, B., \& Sasongko, D. P. (2012). Pemanfaatan jenis pohon lokal cepat tumbuh untuk pemulihan lahan pascatambang batubara. Jurnal Ilmu Lingkungan, 10(1), 19-25.
Ahmad, R. Z. (2018). Mikoremediasi menghilangkan polusi logam berat pada lahan bekas tambang untuk lahan peternakan. Wartazoa, 28(1), 41-50.

Allo, M. K. (2016). Kondisi sifat fisik dan kimia tanah pada bekas tambang nikel serta pengaruhnya terhadap pertumbuhan trengguli dan mahoni. Jurnal Hutan Tropis, 207-217.

Arisusanti, R. J., \& Purwani, K. I. (2013). Pengaruh mikoriza Glomus fasciculatum terhadap akumulasi logam timbal $(\mathrm{Pb})$ pada tanaman Dahlia pinnata. Jurnal Sains dan Seni Pomits, 2(2), 69-73.

Ashofie, I., \& Prasetya, B. (2019). Pengaruh aplikasi kompos dan mikoriza arbuskular pada tailing tambang emas terhadap pertumbuhan dan serapan fosfor tanaman bunga matahari. Jurnal Tanah dan Sumberdaya Lahan, 6(1), 1133-1144. doi:10.21774

Azizah, N., Sari, E., Hidayati, N. A., \& Suyatno. (2020). Mikoremediasi lahan bekas tambang timah tercemar logam $\mathrm{Pb}$ dengan fungi pelarut kalium sebagai biofertilizer potensial. Bioma, 9(2), 229-242.

Bijang, C. M., Latupeirissa, J., \& Ratuhanrasa, M. (2018). Biosorpsi ion logam tembaga (Cu2+) pada biosorben rumput laut coklat (Padina australis). Indoensian Journal of Chemical Research, 6(2), 26-37.

DalCorso, G., Fasani, E., Manara, A., Visioli, G., \& Furini, A. (2019). Heavy metal pollutions: State of the art and innovation in phytoremediation. International journal of molecular sciences, 2. doi:10.3390/ijms20143412

Damodaran, D., Suresh, G., \& Mohan, R. B. (2011). Bioremediation of soil by removing heavy metals using Saccharomyces cerevisiae. 2nd International Conference on Environmental Science and Technology. Singapore

Dariah, A., Abdurachman, A., \& Subardja, D. (2010). Reklamasi lahan eks-penambangan untuk perluasan areal pertanian. Jurnal Sumberdaya Lahan, 1-12.

Dwityaningsih, R., Pramita, A., \& Syarafina, S. (2019). Review potensi tanaman obat akar wangi (Vetiveria zizanioides) sebagai tanaman hiperakumulator dalam fitoremediasi pada lahan tercemar logam. Jurnal Pengendalian Pencemaran Lingkungan (JPPL), 1(1), 51-56.

Ekawati, Mansur , I., \& Dewi, P. (2016). Pemanfaatan kompos dan mikoriza arbuskula pada longkida (Nauclea orientalis) di tanah pasca tambang nikel PT. Antam Pomalaa. Jurnal Silvikultur Tropika, 7(1), 1-7.

Hidayanti, N. (2013). Mekanisme fisiologis tumbuhan hiperakumulator logam berat. Jurnal Teknologi Lingkungan, 14(2), 75-82.

Hidayat, W., Rustiadi, E., \& Kartodihardjo, H. (2015). Dampak pertambangan terhadap perubahan penggunaan lahan dan kesesuaian peruntukan ruang. Jurnal Perencanaan Wilayah dan Kota, 130-146.

Hirfan. (2016). Strategi reklamasi lahan pasca tambang. Jurnal Ilmiah Ilmu-Ilmu Teknik, 101-108. 
Huzeini, A., Suhartoyo, H., \& Susatya, A. (2019). Studi evaluasi pasca tambang PT. Ratu Samban Mining Kabupaten Bengkulu Tengah Provinsi Bengkulu. Jurnal Penelitian Pengelolaan Sumber Daya Alam dan Lingkungan, 29-38.

Idhan, A., \& Nursjamsi. (2016). Aplikasi mikoriza dan pupuk organik terhadap pertumbuhan tanaman kakao (Theobroma cacao L.) di kabupaten Gowa. Jurnal Perspektif, 01(01), 1-11.

Ingwersen, J., Bu“" cherl, B., Neumann, G., \& Streck, T. (2006). Cadmium leaching from micro-lysimeters planted with the hyperaccumulator Thlaspi caerulescens: Experimental findings and modeling. Journal of Environmental Quality, 35: 2055-2065. doi:10.2134/jeq2005.0461

Iram, S., Zaman, A., Iqbal, Z., \& Shabbir, R. (2012). Heavy metal tolerance of fungus isolated from soil contaminated with sewage and industrial wastewater. Polish Journal Environmental Studies, 22(3), 691-697.

Irhamni, Pandia, S., Purba, E., \& Hasan, W. (2017). Serapan logam berat esensial dan non esensial pada air lindi TPA Kota Banda Aceh dalam mewujudkan pembangunan berkelanjutan. Serambi Engineering, 2(1), 134-141.

Irhamni, Pandia, S., Purba, E., \& Hasan, W. (2018). Analisis limbah tumbuhan fitoremediasi (Typha lltifolia, enceng gondok, kiambang) dalam menyerap logam berat. Serambi Engineering, III: 344-351.

Javaid. (2011). Importance of arbuscular mycorrhizal fungi in phytoremediation of heavy metal contaminated soils. New York: Springer Inc,.

Joshi, P. K., Swarup, A., Maheshwari, S., Kumar, R., \& Singh, N. (2011). Bioremediation of heavy metals in liquid media through fungi isolated from contaminated sources. Indian Journal of Microbiology, 51(4), 482-487.

Kartika, E., Lizawati, \& Hamzah. (2018). Respon tanaman jarak pagar terhadap mikoriza Indigenous dan pupuk di lahan bekas tambang batu bara. Biospecies, 11(1), 11.

Khan, M. I., Khisroon, M., Khan, A., \& Naila, G. (2018). Bioaccumulation of heavy metals in water, sediments, and tissues and their histopathological effecs on Anodonta cygnea (Linea, 1976) in Kabul River, Kyber Pakhtunkwa, Pakistan. Biomed Reserach International, 1-11.

Komarawidjaja, W., \& Garno, Y. S. (2016). Peran rumput vetiver (Chrysopogon zizanioides) dalam fitoremediasi pencemaran perairan sungai. Jurnal Teknologi Lingkungan, 17(1), 7-14, ISSN: 1411-318X.

Mashud, N., \& Manaroinsong, E. (2014). Pemanfaatan lahan bekas tambang batu bara untuk pengembangan sagu. B. Palma, 56-63.

Munir, M., \& Setyowati, R. D. (2017). Kajian reklamasi lahan pasca tambang di Jambi, Bangka dan Kalimantan Selatan. Klorofil, 11-16.
Muryati, S., Mansur, I., \& Budi, S. W. (2016). Keanekaragaman fungi mikoriza arbuskula (FMA) pada rhizozfer Desmodium spp. asal PT Cibaliung sumber daya, Banten. Jurnal Silvikultur Tropika, 07(3), 188-197.

Nadeak, J. O., Delvian, \& Elfiati, D. (2015). Pengaruh pemberian fungi mikoriza arbuskula (FMA) terhadap kandungan logam timbal $(\mathrm{Pb})$ pada tanaman sengon (Paraserianthes falcataria). Peronema Forestry Science Journal, 4 (3), 7.

Nuriadi, Napitupulu, M., \& Rahman, N. (2013). Analisis logam tembaga $(\mathrm{Cu})$ pada buangan limbah tromol (tailing) pertambangan Poboya. Jurnal Akademika Kimia, 2(2), 90-96.

Nusantara, A. D., Bertham, Y. H., \& Mansur, I. (2012). Bekerja dengan fungi mikoriza arbuskula. Bogor: Seameo biotrop.

Orlowska, E., Orlowski, D., Przybylowicz, J. M., \& Turnau, K. (2011). Role of mycorrhizal colonization in plant establishment on an alkaline gold mine tailing. International Journal of Phytoremediation, 13(2), 4. doi: 10.1080/15226514.2010.495148

Prasetyo, R., Sasli, I., \& Ramadhan, T. H. (2019). Identifikasi vegetasi dan fungsi mikoriza arbuskular (FMA) pada lahan bekas tambang. Jurnal Agron Indonesia, 217-223.

Pulungan, A. S. (2018). Tinjauan ekologi fungi mikoriza arbuskula. Jurnal Biosains, 4(1), 17-22.

Rosahada, A. D., Budiyono, \& Dewanti, N. A. (2018). Biokonsentrasi logam berat tembaga $(\mathrm{Cu})$ dan pola konsumsi ikan mujair di wilayah danau Rawapening. Jurnal Kesehatan Masyarakat (e-Journal), 6(6), 1-7.

Sarie, H. (2019). Potensi bahaya kontaminasi logam berat di lahan bekas tambang batubara yang digunakan sebagai lahan pertanian. Buletin LOUPE, 15(2), 31-41.

Sarma, H. (2011). Metal hyperaccumulation in plants: A review focusing on phytoremediation technology. Jurnal of Environmental Science and Technology, 4(2), 118-138.

Setiawan, H. (2015). Akumulasi dan distribusi logam berat pada vegetasi mangrove di pesisir Sulawesi Selatan. Jurnal Ilmu Kehutanan, 7(1), 12-24.

Sofyan, R. H., Wahjunie, E. D., \& Hidayat, Y. (2017). Karakterisasi fisik dan kelembaban tanah pada berbagai umur reklamasi lahan bekas tambang. Buletin Tanah dan Lahan, 72-78.

Subowo. (2011). Penambangan sistem terbuka raham lingkungan dan upaya reklamasi pasca tambang untuk memperbaiki kualitas sumberdaya lahan dan hayati tanah. Jurnal Sumberdaya Lahan, 83-94.

Suharno, \& Sancayaningsih, R. P. (2013). Fungi mikoriza arbuskular: Potensi teknologi mikorizoremediasi logam berat dalam rehabilitasi lahan tambang. E-ISSN: 23018658. Bioteknologi, 24. doi: 10.13057/biotek/c100104 
Sukmawaty, E., \& Asrian. (2015). Keanekaragaman mikorza arbuskula Indonesia dan peranannya dalam ekosistem. Jurnal Biotek, 3(1), 45-51.

Suryati, T. (2017). Studi fungi mikoriza arbuskular di lahan pasca tambang timah. Jurnal Teknologi Lingkungan, 4553.

Takács, T. (2012). Site-specific optimization of arbuscular mycorrhizal fungi mediated phytoremediation in: Toxicity of heavy metals to legumes and bioremediation. Toxicity of heavy metals to legumes and bioremediation. doi:10.1007/978-3-7091-0730-0_11

Talanca, H. (2010). Status cendawan mikoriza vesikulararbuskular (MVA) pada tanaman. Prosiding pekan serealia nasional, 353-357.
Thamrin, \& Raden, I. (2018). Reklamasi lahan pasca tambang batubara menjadi lahan produktif di Kabupaten Kutai Kartanegara. Jurnal Magrobis, 18(2), 49-56.

Tuheteru, F. D., Arif, A., Widiastuti, E., \& Rahmawati, N. (2017). Serapan logam berat oleh fungi mikoriza arbuskular lokal pada Nauclea orientalis dan potensial untuk fitoremediasi tanah sepertine. Jurnal Ilmu Kehutanan, 77.

Ulfa, M., Kurniawan, A., Sumardi, \& Sitepu, I. (2011). Populasi fungi mikoriza arbuskular (FMA) lokal pada lahan pasca tambang batubara. Jurnal Penelitian Hutan dan Konservasi Alam, 8(3), 3

Zaidi, A., Saghir, M., \& Wani, P. A. (2012). Toxicity of heavy metals to legumes and bioremediation. New York: Springer Inc. 